\title{
Historical Enquiry as a Critical Method in Urban Riverscape Revisions: The Case of Belgrade's Confluence ${ }^{\dagger}$
}

\author{
Marija Milinković ${ }^{1, *}$, Dragana Ćorović ${ }^{2}$ (i) and Zlata Vuksanović-Macura ${ }^{3}$ (i) \\ 1 University of Belgrade-Faculty of Architecture, Bulevar kralja Aleksandra 73/II, 11000 Belgrade, Serbia \\ 2 University of Belgrade-Faculty of Forestry, Kneza Višeslava 1, 11030 Belgrade, Serbia; \\ dragana.corovic@sfb.bg.ac.rs \\ 3 Geographical Institute "Jovan Cvijić" SASA, Djure Jakšića 9, 11000 Belgrade, Serbia; z.macura@gi.sanu.ac.rs \\ * Correspondence: marija.milinkovic@arh.bg.ac.rs; Tel.: +318-11-3218-751; Fax: +381-11-3370-193 \\ + This is an expanded version of the paper presented at the conference Landscape Futures UNISCAPE \\ Conference 2017, Copenhagen, Denmark, June 19-21 2017. The abstract of the paper was published within the \\ Book of Abstracts (p. 53; https://ign.ku.dk/landscape-futures/pdf/LandscapeFutures_BookofAbstracts.pdf).
}

Received: 21 January 2019; Accepted: 18 February 2019; Published: 22 February 2019

check for updates

\begin{abstract}
This article aims to underline the necessity of including historical enquiry in reaching the complex goals of sustainable development of urban riverscapes. Its proposed method is a survey conducted through selection, interpretation and systematization of the relevant historical data that consider the Belgrade cityscape, and specifically, the New Belgrade public spaces at the river confluence. The theoretical framework, which relies on the concepts of 'landscape urbanism' and 'critical practice of landscape architecture', has affected the selection and interpretation of dense historical layers of modernization, formed in diverse socio-economic and political conditions. We have distinguished five historical strata that contribute significantly to comprehension of the present state. By looking at the traces of the formative period of Belgrade urban landscape, the moments of New Belgrade's inception, inerasable impacts of war, vigorous post WWII socialist transformation and, finally, the series of Danube riverscape revisions, we intend to depict the complexity of the modern city legacy and thus stress the interconnectedness of past and future endeavours. As a counterpoint to globalizing tendencies in re-designing city riverfronts, this work is conceived as a lateral contribution to a broader investigation that informs, supports and constitutes more ecologically viable practices.
\end{abstract}

Keywords: New Belgrade riverscape; Danube; urban landscape; urban open spaces; historical enquiry; landscape urbanism; critical practice

\section{Introduction}

The creation of urban landscapes is considered in this study from the perspective of the synthesis of nature and culture under specific historical circumstances. The transformation of an urban landscape is the transformation of a space which, in turn, is in any given historical period bound up with the history of the space. It is not only, as Henri Lefebvre writes, 'geographical descriptions of natural space', but the study of 'natural rhythms' and of change in the 'spatio-temporal rhythms of nature', which reflect the social practices inscribed into the space [1] (p. 117). A river, as both a flexible and a firm element of urban landscape has potential as a mediator to express the complexity of its ever-changing images [2]. Though the term 'riverscape' designates the landscape around a river, even a view of a river, its more profound meaning points to its complex structure comprising organic and inorganic elements and their interconnectedness across change. As S. M. Haslam pointed out: 
"The river continuum is of time as well as space, as is that of the riverscape, changed, slowly or dramatically, over the years. The land form continues, the rest changes" [3] (p. 149).

The historical data that document these changes thus reveal the main phases of urban landscape transformation. In this article, we emphasise the importance of (historical) study of the riverscape of Belgrade, given that the city is situated "[...] on the largest water junction of Europe" [4] (p. 319) - the confluence of the Sava river into the Danube. Positioned on the Balkan Peninsula, Belgrade is geographically situated between the Pannonian Plain and the mountainous area of Šmadija. The historical core of the city is located between the two slopes above the rivers, which also give it its strategic importance. Being wedged between geographical oppositions is also reflected in its multi-layered history: "In geopolitical terms, ever since the split of the Roman Empire and into modern history, the two rivers formed borders between often conflicting empires (i.e., between Eastern and Western Roman Empires, Franks and Byzantine Empire, and Ottoman and Austrian/Austro-Hungarian Empires)" [5] (p. 53). Today, Belgrade is the capital and the largest city in the Republic of Serbia, which it also was in former Yugoslavia, 1918-2006. The metropolitan area of Belgrade covers more than 320,000 hectares, with 17 municipalities and nearly 1.7 million people.

Facing a moment of profound change in Belgrade riverscape, our study is focused on the city's central green core and the large open public space on the right bank of the Danube. Following Christophe Girot's notion that "[e]ach time a landscape project begins there should follow an extended period in which one may simply discover what already exists" [6] (p. 65), we have undertaken a historical survey in attempt to grasp both perceptible and 'not so obvious' layers of modernisation, inscribed into the peculiar site of the urban park Ušće (confluence in Serbian). Even though historical enquiry is considered a standard methodological procedure and supposedly forms a common part within the practice of landscape architecture and urban design, under pressure from time-saving and profit-based demands of the capitalist economy, this step is often neglected or severely reduced. Being aware of these reductions and their consequences, the survey starts from a general question: how to acquire profound knowledge and experience, as proper introduction to a site project? Knowing that the dominant paradigm of contemporary city development has already been framed for decades by the universal idea of sustainability [7], we intend to explore ways to approach interventions in the modern city, and furthermore, how to relate to a modern city that was conceptualised and realised within a socialist society-to wit, the capital of former Yugoslavia.

In this endeavour, we refer to the theoretical framework constructed around the concept of 'landscape urbanism', that was initially articulated through the Landscape Urbanism academic program at the University of Illinois, the Landscape Urbanism conference, 1997, and the Landscape Urbanism traveling exhibition curated by Charles Waldheim, 1997-1998 [8]. The discipline progressed particularly through the work of, besides Waldheim, James Corner and Mohsen Mostafavi, and many other educators, theorists and practitioners, such as Sébastian Marot, Kelly Shannon, Julia Czerniak, Richard Weller, Anita Berrizbeitia, Christophe Girot, etc. This hybrid field of work cuts across numerous disciplines, in "an attempt to re-emphasise the importance of particular sites and the ecological/artificial processes they encompass" [9] (p. 626). Emphasizing that the very concept of landscape contains both a spatial milieu and cultural image, Corner notices that landscape ideas are not universally shared: "it is crucial to understand how cultural ideas condition construction and how construction, in turn, conditions the play of landscape ideas in a larger cultural imagination" [6] (p. 8).

In this respect, we stand with many scholars in assuming that proper introduction to a site project should include 'a closer look' [6,9-14], implemented through very well-known methodologies of landscape site analysis [14], and improved by the contemporary approach of landscape urbanism. Starting from the premise that the concept of urban landscape offers a generic approach for revealing and re-imagining the unique features of the particular site, as well as the tools to actively resist the globalizing and homogenizing tendencies in contemporary practices [11], our intention is to distinguish layers of historical, natural, social, environmental, cultural and political specificities of the New Belgrade landscape (Figure 1). For reading the material and immaterial traces of the past, and detecting 'not so obvious' 
features of the present condition, we shall rely particularly on the peculiar notions of 'critical practices in modernism', recently proposed by Anita Berrizbeitia and Karen M'Closkey [15].



Figure 1. The confluence of the Sava into the Danube at Belgrade. Photo source: Tourist Organization of Belgrade, public domain.

Concerned primarily with serious ecological threats, the discourse of sustainability itself is, for many reasons, strongly influenced and supported by the contemporary wealth of scientific knowledge, technological innovations and unforeseeable technical inventions. However, the aim of this paper is to stress the necessity of including a historical and cultural perspective in reaching progressively more complex goals of sustainability. Formation of public green spaces in the city may be a process of critical change and enrichment of cultural conventions. The landscape that is being acted upon becomes the tool for establishing the ensemble that will, through its usage, fulfil a certain planned spatial strategy. Besides dealing with contemporary environmental issues, the restoration of green areas of the city, together with studying the memory they hold, can contribute significantly to a reduction of current "cultural amnesia" [6] (p. 59), and thus the materialization of cultural diversity. Therefore, the significance of this paper may be found in its lateral contribution to contemporary debates on sustainable urban growth and achieving urban resilience: in pointing out the shortcomings of the prevalent ad-hoc approach to site survey, i.e., superficial analysis of the current state of affairs, and in proposing an alternative, critical mode of spatial and historical enquiry. Finally, we would argue that urban riverscape revisions of the post-socialist society should act as a trigger for the community, along with variously profiled experts, to cope with broad environmental and social challenges.

\section{Theoretical Framework}

There are numerous definitions of a landscape. According to one of them, it is: "a portion of the earth's surface that can be comprehended at a glance" [16] (p. 8). Another writer states: "The meaning of 'landscape' shifts by the context and by the background of the users" [17] (p. 13). The human role in landscapes is dissimilar to that of other species, precisely due to the imprint of cultural patterns that 
characterise human activity. A new cultural landscape emerges through the activity of cultural groups in a natural setting [18]. Dealing with the study of theory and practice in relation to the concept of landscape in the 20th century, John Wylie starts his book with the following statement: 'Landscape is tension' [19] (p. 1). Dialectical pairs of terms: 'proximity-distance', 'observation-inhabitation', 'eye-land' and 'culture-nature' are the contrasts that create tension and define the critical view of a landscape. Within the same theoretical discourse, the concept of landscape is explained by studying the dialectic pair of terms: 'production-representation', accentuating the existence of the mutual dependency between the manner in which a certain landscape is presented and production of the social, spatial and aesthetic values that can be perceived in that landscape $[20,21]$. In the past decades in particular, landscape was established as a means of mediation, on the basis of which the position and role of all social levels of a society can be recognised.

The theoretical concept of urban landscape, with its extended field of spatial agencies, brought new modes of thinking and acting within the field of landscape architecture [9]. In keeping with the ideas of contemporary practice of landscape urbanism, we would contend that with some thoughtful projects in this domain, such as Freshkills Park, New York (James Corner Field Operations), The BIG $U$, New York (BIG TEAM), Resilience + The Beach, New Jersey (Sasaki, Rutgers, Arup), new modes of critical landscape practice have emerged. If, following Berrizbeitia and M'Closkey, we understand the term 'critical practice' as the activity that is, in Max Horkheimer's words, "explanatory, practical and normative" [15] (p. 207), the critical projects of landscape architecture might be detected in various historical, cultural and socio-political contexts. As Berrizbeitia and $\mathrm{M}^{\prime}$ Closkey have shown, criticality in the formative period of American landscape architecture was les manifested in formal than in methodological terms. The texts and projects that have rejected or resisted colonial and post-independence modes of land tenure have operated within the existing institutional and political framework of nineteenth century "laissez-faire capitalism, broadly institutionalized since colonialism; accelerated urbanization; and, as a result of these, an environmental crisis not unlike the one we face today" [15] (p. 208). The authors of this insightful study found the predecessors of critical practice within landscape architecture in enterprises that produced formal, material and programmatic ruptures in the existing empirical realities, while offering innovative technical and material proposals, "satisfying the goals of both capitalism and environmentalism" [15] (p. 222).

This particular mode of immanent critique, which operates within imposed real-world conditions, and differs from radical, transcendental, that is, avant-garde critique, is labelled experimental by architectural theorist Manfredo Tafuri [22,23]. By the same token, some of the early projects for Belgrade landscape and riverscape revisions could also be distinguished as exemplary of the immanent critique. In this context, we shall underline the insightful plan made by the prominent architect Dimitrije T. Leko (1863-1914), for the regulation of the Danube bank in the old part of Belgrade, at the very beginning of the twentieth century. Leko was also known for his polemical articles dedicated to various problems in the urban development of Belgrade. In his writing, Leko pointed to the difficulty of urbanisation in conditions determined by 'big capital'. He advocated for revisions to the urban regulation plan of the time, as well as construction laws. In an article from 1901 [24], Leko discusses the issue of the Danube quay and expansion of the Danube neighbourhood, and addresses the question of the regulation of the riverbank. After the Second World War, renowned modernist architect and town planner Nikola Dobrović (1897-1967), just like Leko several decades earlier, proposed city plans with a strong critical attitude. Space as an unbroken whole was at the core of Dobrovićs idea of city landscape, explicitly conceptualised in 1954. The term city landscape, in German Stadtlandschaft, belongs to the history of German urban planning and emerges as a doctrine for the creation of large-scale urban settlements shortly after the Second World War [25] (p. 141). In Yugoslavia, Nikola Dobrović was among the first to consider the concept of city landscape [26], writing of it as a term still being defined, describing its versatile nature as: "a new type of spaciousness of buildings and their plasticity, the hollow plasticity of the in-between spaces, architecture of the ground, greenery and the vistas in one organically designed composition whole" [27] (p. 1). Dobrović explicitly connects the equality in space 
quality with given social values. He wrote that only an urbanism "comprehended and experienced as an organic assembly of city landscapes, can represent the reflection of social aspirations and spirituality of modern" [27] (p. 3).

\section{Methodological Framework}

Each time a critical project emerges, it relates to what already exists. Yet, historical surveys are particularly underestimated and circumvented, often regarded as an obstacle to pursuing both the designer's artistic freedom and goals of capitalist growth. Thus, surveys of the present state of affairs and its historical background often do not take enough space and time in preparing for future spatial interventions. In this study, we shall focus on the benefits of profound historical research, given that a preliminary survey of specific urban conditions should rely mostly on the proper collection, systematization and interpretation of heterogeneous data. Therefore, our research is not based on well-established disciplinary methods, such as historical-interpretative research. Instead, having in mind the specific context of this study, we have combined the analytical method of identification of relevant historical data with the synthetic method of superposition of identified historical layers [12].

The process of detecting important historical data that refer to a certain area of research, along with the identification and evaluation of the landscape layers, are probably the most intriguing and most sensitive aspects of spatial revision inspection. The mutual relations of urban historical layers and various factors involved in contemporary urban transformation also reflect the inhabitants' relationship to past values, as well as the relationship between the past, the present and the future of landscapes. The contemporary transformation of the New Belgrade riverbank, that is, the park that extends along the right bank of the Danube, at the Sava river confluence, has prompted our examination of the key concepts of urban planning-specifically, periods of rapid revision that took place at the beginning of the twentieth century, as well as after the Second World War. By comparing and analysing these revisions, we have tried to show the lost layers that reveal valuable traces of modernisation and modernity in the metamorphosis of riverine landscapes.

The view can never be directed towards the landscape in general, but spontaneously steers and unmistakably stops at the stable, conspicuous points that 'capture' the attention of the observer. Instantly afterwards, the mind of the observer tries to understand the limits of the landscape and to comprehend the whole [28]. We use these insights in an effort to find the most appropriate methods and techniques to highlight important cross sections of the meaningful layers and complex transformations of the Belgrade and New Belgrade riverscape.

The bulk of material for this study originates from the relevant primary and secondary sources, related to proposed methods. It contains material from historical archives, such as: maps, documents, plans, photographs, publications and written sources from the analysed periods. Also, it relies profoundly on previous investigations by prominent researchers and scholars, our own previous research into the urban landscape and urban history of Belgrade, as well as research regarding critical practices of modern architecture in Yugoslavia. This study is based on our findings in the search for more profound knowledge of mutual relations of the urban historical layers and the various factors involved in the contemporary urban transformation of the city. Finally, the research is informed by the material from public and private photo archives.

\section{The Historical and Cultural Layers of Collective Memory}

Serbia was under Ottoman rule in the period from 1459 to 1878. In the course of the Ottoman expansion in the 14th and 15th centuries, the Balkans, or the "fortified peninsula" [29] (p. 511), became part of a territory ruled by the Ottoman Sultan, and Belgrade became part of the Ottoman empire in 1521. We trace here the 'dynamics of cityscape revisions' far back in time, to 1717, when the Austrians took the Belgrade fortress from the Ottomans and started reconstruction of the city. The Sava and Danube rivers were the state border, established during the great Turkish war 1683-1699. The border existed until 1918, with a short exception from 1717 to 1739 and from 1788 to 1791 . The waterline, as a 
natural boundary and state border for almost two centuries, brought about the expansion of Belgrade east and south of the rivers (Figure 2a,b).

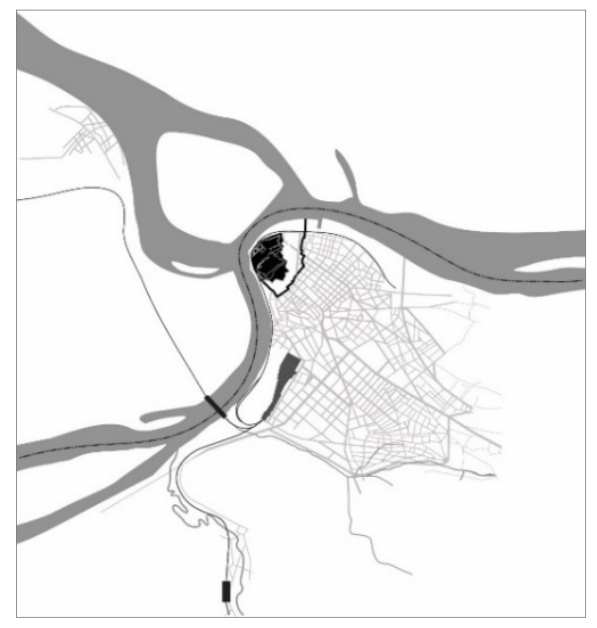

(a)

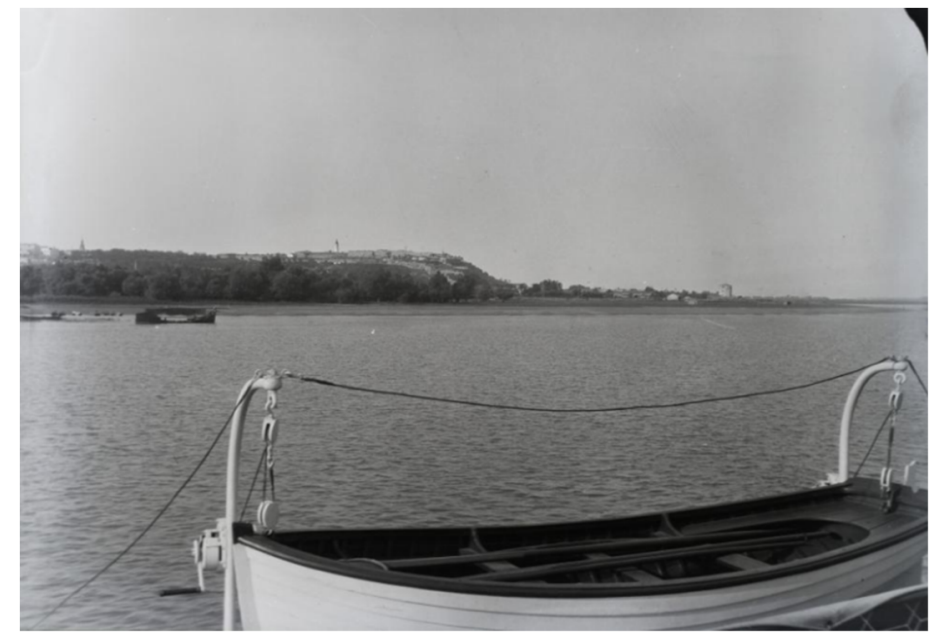

(b)

Figure 2. (a) A map/diagram of Belgrade in 1918 (design by Slobodan Radosavljević); (b) The Danube opposite the Belgrade Fortress: the view from the Zsófia Herczegnó luxury steamer. Photo from 1916. Source: http:/ / www.fortepan.hu/_photo/display/132360.jpg; image 23/170; image ID: 132360. Original: Magyar Mûszaki És Közlekedési Múzeum/Archívum/Negatívtár/Özv Venczel Jánosné Gyújteménye; inventory reference: MMKM TFGY 2017.10.111.

\subsection{Layers of Belgrade Landscape of Modernisation: The Formative Period (1867-1914)}

The 19th century Western technological developments in spatial transformation were applied considerably less in Serbia. The most radical period of communal modernization of Belgrade occurred only at the end of the century. It was also the moment of the most radical transformation of Belgrade urban landscape: from an Ottoman to a European city. Unfolding through the conversion of the natural setting, the space surrounding the city core was turned into a new urban environment. Belgrade's urban landscape transformation accelerated after the newly formed Principality of Serbia (which lasted from 1815 until 1882 when it became a Kingdom) acquired a sufficient level of autonomy from the Ottoman Empire, that is, after 1829. The protagonists of this transformation were the bearers of political and economic power that followed the patterns of capitalist development of state and social structure. This process intensified considerably following the Congress of Berlin and full Serbian independence, in 1878. It was driven by the opposition between the Balkan and Ottoman heritage on the one hand, and the declaratively embraced European model on the other. The major metamorphosis of the urban landscape of Belgrade is characterized by the decades of implementation of the regulation plan, authored and published in 1867 by the engineer Emilijan Josimović [30]. He devoted considerable attention in his plan to the regulation of river flow and construction of quays and harbours. This period also saw the building of modern infrastructure systems, directly exercising a qualitative change in everyday life: the construction of railways in 1884, a modern water supply system in 1892, installation of public lighting and electricity in 1893, establishment of public transportation in 1892 and modern sewerage in 1905.

\section{4: Leko's Project for the Danube Riverbank}

In his regulation plan for the historical core of the city, Josimovic proposed the forestation of the Danube riverbank. Several decades later, however, in 1904, Leko suggested a project for the construction of a Danube quay. This would allow for the expansion of the city to the river, given that at the time, of the $6 \mathrm{~km}$ of riverbank, Belgrade made use of only $300 \mathrm{~m}$. In the Danube quay regulation 
plan, Leko included the formation of a park with fishponds along the existing railroad. It was supposed to create a harmonious whole that would solve the issue of floods and remove underground waters, all the while providing a large and lush green area adjacent to the Danube residential neighbourhood (for which he also created a plan in 1904) (Figure 3a).

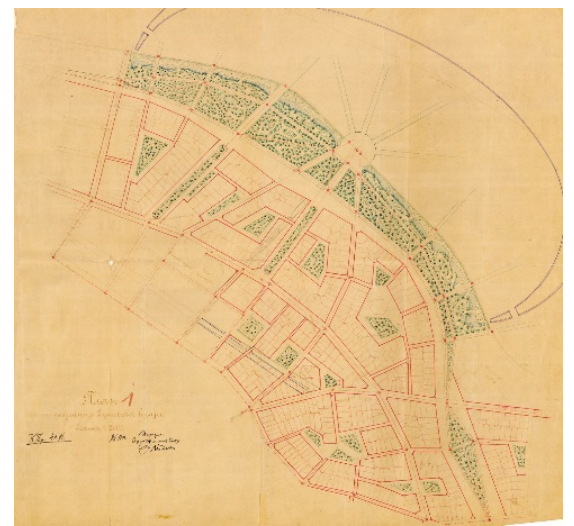

(a)

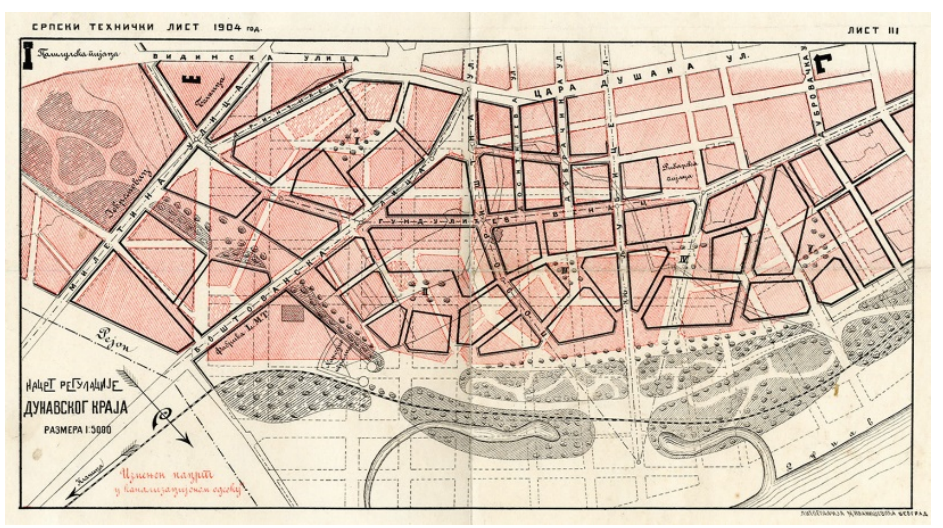

(b)

Figure 3. (a) Dimitrije T. Leko, Plan for the Danube neighbourhood, 1:2000, 1904. Source: [21] (p. 398); (b) Superimposed plans for the Danube neighbourhood by Dimitrije T. Leko, and the changes made by the Sewage Department of the Municipality of Belgrade, 1:5000, 1904. Source: [21] (p. 397).

Leko devised the plans for the quay and the neighbourhood in his capacity of municipal architect, but they were never executed. They were replaced with another plan, developed by the Sewage Department of the Municipality of Belgrade-although this one was not realised either. Superimposed versions of these plans (Figure $3 \mathrm{~b}$ ) speak to the constant revisions and alterations in the plan's conception, the various relationships towards the riverbank, the uncertainty of effect of the decisions passed and the hesitation in their realisation. The concept of the neighbourhood ultimately produced by the Municipality annulled Leko's ideas, which were devoted to the achievement of the economy of building, possibility of mixed social housing and experimentation with city quarters [21].

\subsection{Layers of New Belgrade Landscape: The Inception (1918-1940)}

With the end of the First World War and the formation of the Kingdom of Yugoslavia, the Sava and Danube ceased to be the border. The broad wetlands on their left banks were perceived as an integral part of the city landscape. The first urban-planning step onto the left bank of the Sava was made in 1921-1922 with the international competition for the General Plan for the beautification and enlargement of Belgrade. The competition program envisioned the new main city port with accompanying facilities on the terrain between Belgrade and Zemun. Competition entrants followed the program instruction, but they also proposed the construction of new residential and industrial districts, such as the French authors whose project bore the motto Urbs Magna (Figure 4a). Furthermore, there were ideas for the formation of an artificial lake on the arm of Danube, construction of sport complexes, stadiums, and parks. Viennese authors, under the motto Singidunum Novissima (Singidunum was the Roman name of Belgrade), observed the wetlands on the left bank of the Sava as the dominant and most favourable space for the future expansion of the city [31]. In 1923, based on ideas from various competition entries, the first official draught plan for the future New Belgrade was formulated by George Pavlovich Kovalevsky, an engineer of Russian origin and a leading urban planner in interwar Belgrade. However, the draft did not become part of the adopted General Plan from 1923-1924, due to the fact that the territory on the left bank of the Sava did not fall under Belgrade administrative authority, but belonged to the municipality of Zemun. 


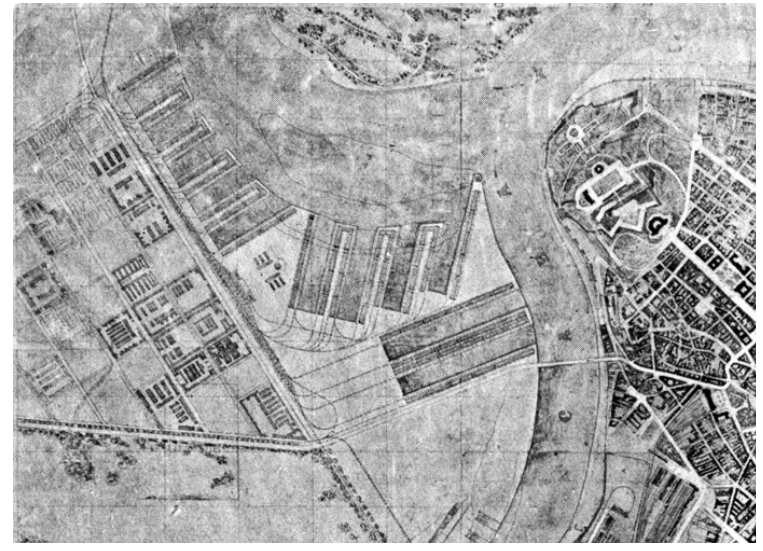

(a)



(b)

Figure 4. The interwar plans for the terrain on the left bank of the Sava River (a) Competition project Urbs Magna, by the French authors, 1921-1922. Source: [31] (p. 118); (b) Plan of urban regulation for inundated terrain between Zemun and Belgrade, by George Pavlovich Kovalevsky, 1932-1934. Source: [32] (p. 208).

A decade after the international competition, in 1932-1934, Kovalevsky developed a new regulation plan for the area between Zemun and Belgrade [32]. The dominant elements of the plan were the urban matrix that followed the pattern of old Belgrade and the major axis, that is, the wide boulevard connecting Belgrade and Zemun (Figure 4b). Although Kovalevsky's second plan was not executed either, Zemun did become administratively part of Belgrade. The first real act unifying the two river banks was the opening of the chain bridge in 1934. This act spurred both spontaneous and planned construction in the newly acquired space. The first settlement was by Belgrade's poorest inhabitants, still standing today. Then, 1937 saw the construction of the exhibition halls of the Fairgrounds - whose opening was a first-rate social occasion. The city authorities hired the Danish firm Höjdegard \& Schultz to cover the marshy terrain with sand drawn from the Sava, turning the area into construction real estate. The Danish company deposited sand where the park Ušće stands today. On the eve of the Second World War, the built landscape of New Belgrade consisted of one low income settlement and the colourful Fairgrounds complex. The latter included a transit camp, erected in 1940, for the collection of Bessarabian Germans being relocated to Germany, which would prove a foretaste of wartime events when the Fairgrounds served as a Nazi concentration camp.

\subsection{The War Landscape (1941-1945)}

What was built in 1937 as the Belgrade Fairgrounds of the Yugoslav capital, during the war time became a place of an atrocious crime [33]. After the Axis invasion of Yugoslavia, the Fairgrounds became a concentration camp for the internment of Jews, Jugendlager Semlin, established by Nazi Germany. The camp fell within the territory of the newly proclaimed Independent State of Croatia. In May 1942, it was given the status of Anhaltslager Semlin, and its prisoners were transported to different labour camps in Germany: "a temporary detention camp for political prisoners, captured Partisans and forced labourers, most of whom were subsequently transported to various labour camps in Germany. Between May 1942 and July 1944, 32,000 inmates (mainly Serbs) passed through the camp, of which 10,600 were killed or died of starvation, exposure, or disease. Semlin was the largest concentration camp in Nazi-occupied Serbia" [34]. During the Allied bombing raids from June to September of 1944, the former fairground was almost completely demolished. While the fairground's adaptation to a concentration camp may be explained as an almost perfect match, pointedly noted by Ljiljana Blagojević, after the war, this place of horror became, in her words, "an undesirable reminder of monstrous events" [26] (p. 262). 


\subsection{Post WWII Layers of New Belgrade Landscape: The Transformation (from 1946)}

The most profound transformation of the New Belgrade urban landscape started after the Second World War, with the construction of the new capital of the socialist state, Federal People's Republic of Yugoslavia (from 1963, the Socialist Federal Republic of Yugoslavia). The deserted space on the left bank of the Sava, between Belgrade and Zemun, went from a sketch well-nigh developed by one person, through innumerable iterations and revisions of plans, becoming a city of more than 200,000 inhabitants. The initial concept was made in 1946, by Nikola Dobrović and his team from the Institute of Urban Planning. Although already present in mental and factual maps of the city, and infamously used during the Second World War for concentration camps, the flat wetland on the left bank of the Sava entered planning procedures as an 'empty' space [26].

\subsubsection{6: The Draft}

After the Second World War, the area of the confluence represented a special locus in the Communist Party's vision of the new capital of the Yugoslav Federation. In rising to this exceptional task, Nikola Dobrović organized the Group for New Belgrade, a new working team at the Institute for Urban Planning of Serbia. By 1946, in coordination with the Group, he produced the 'Draft for the regulation of Belgrade on the left bank of the river Sava' (Figure 5a). In contrast to Kovalevsky's plan from 1934, Dobrović's adopted radial street matrix challenged the static, academic solutions and strived for a critical rethinking of classical schemes. The buildings themselves no longer formed the perimeter block, but stood as solitary objects in the park, and the modern railway station was placed in the very heart of the new administrative centre.

This pioneering work was preceded by two research studies. In the very first publication of the Institute, entitled The Railroad Problem of Belgrade, the central issue was the city traffic and its key role in a contemporary metropolis [35]. Following recommendations from the Athens Charter, Dobrović and the co-author of the text, Vladimir Marković, suggest a radical revision of the railroad system and the relocation of Belgrade's main station, as the current one prevented contact between the city and its rivers. The 'Conceptual plan of land use for Belgrade' (Figure 5b) was derived from this study, and was the first post-war urban proposal of the new, integral city plan. Dobrović particularly insisted on inventing a new methodology in planning practice, claiming that "it is impossible to apply the same worn-out working methods, following the usual formalism, as practised before" [36]. The main aspects of this new methodology were "from the individual towards team work, and from specialist to synthetic expert and socio-political decision-making" [37] (p. 17).

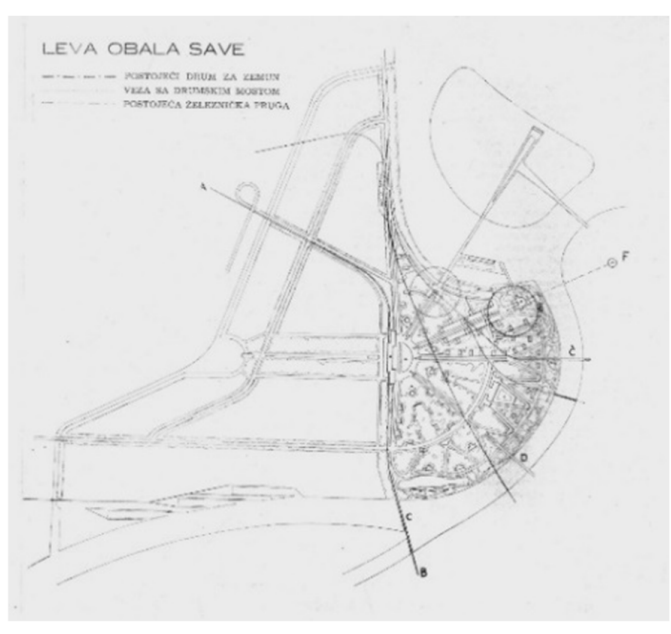

(a)

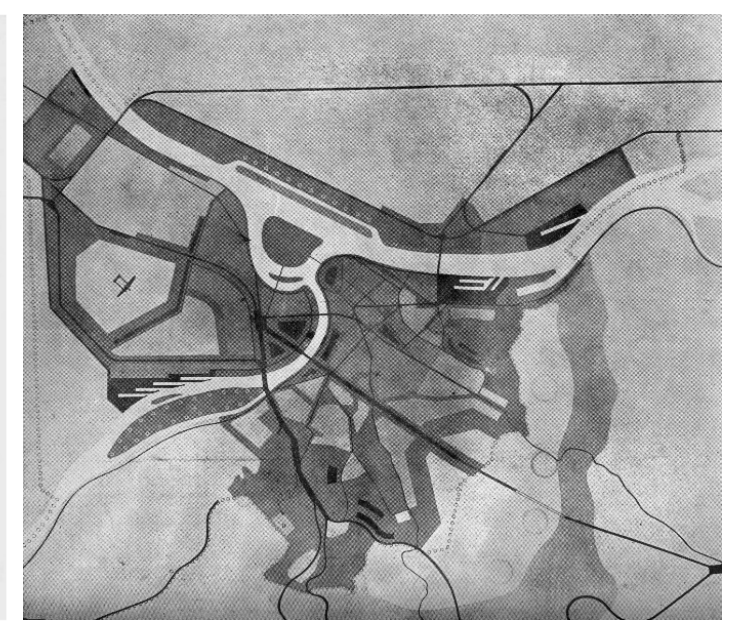

(b)

Figure 5. (a) Draft for the regulation of Belgrade on the left bank of the Sava, 1946. Source: [38] (p. 353); (b) Conceptual plan of land use for Belgrade, 1946. Source: [39] (p. 25). 


\subsubsection{7: The all-Yugoslav Competitions}

Soon after the presentation of the Draft, it was decided that the questions of the new Federation capital should be discussed on a broader, federal level. The Draft was used as an initial announcement for a set of general all-Yugoslav competitions for a master plan of New Belgrade and three key buildings of the new administrative centre of the Federation: the building of the Central Committee of the Communist Party of Yugoslavia, the building of the Presidency of the Government and a representative hotel, later named Hotel Yugoslavia. The dynamics of construction differed in all three cases, but the initial plan was finally accomplished, and by the mid 1960s all of them became highly representative buildings of the socialist modernism in architecture. The fan-shape plan was rejected in most competition proposals and the scope of the solutions offered varied from those that reflected the Soviet planning methodology to those that conformed to Le Corbusier's conceptions and the recommendations of CIAM. The supposed initial hegemony of the Draft was superseded in the 1947 discussions, when the questions of architecture and urbanism of New Belgrade mobilized a large number of Yugoslav experts: architects, engineers, urban planners, artists and workers in the fields of cultural and social life [37].

\subsubsection{8: The Conceptual Plan}

In January 1948, the 'Conceptual Plan of Greater Belgrade' was presented to the public in a model scaled 1:10,000, along with the 'Conceptual Plan of New Belgrade' in a model scaled 1:5,000 (Figure 6a). The imposing physical model comprising the area of New Belgrade together with the riverfront of the right bank of the Sava was a considerable departure from the Draft's initial setup. The street matrix was a regular grid and the plan conformed more closely to the propositions of the Athens Charter. The plan also suggested the construction of a navigable channel between the two rivers with a tripartite artificial lake in the middle zone that was justified by the savings it would bring in earthworks. The Conceptual Plan interpreted the modernist paradigm freely and un-dogmatically, and actually offered a novel approach in modern urban planning, the one that Dobrović later described as the city landscape [27]. It relied on the connecting potential of the green areas while insisting on an organic quality of space, continuity and movement. Dobrović maintained that the unified, continual tissue of the socialist city should be perceived just like in motion pictures: produced by the cohesive forces of the collective will, it would provide an unbroken progression of spatial units, perpetually permeated and united. With the Conceptual Plan, the city landscape of New Belgrade turned from homogeneous space of an administrative district, into a complex and heterogeneous city matrix, with the large housing blocks in its very centre [40] (Figure 6b).

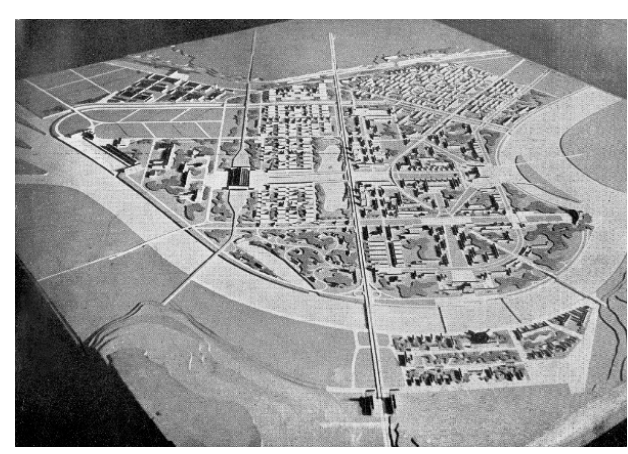

(a)

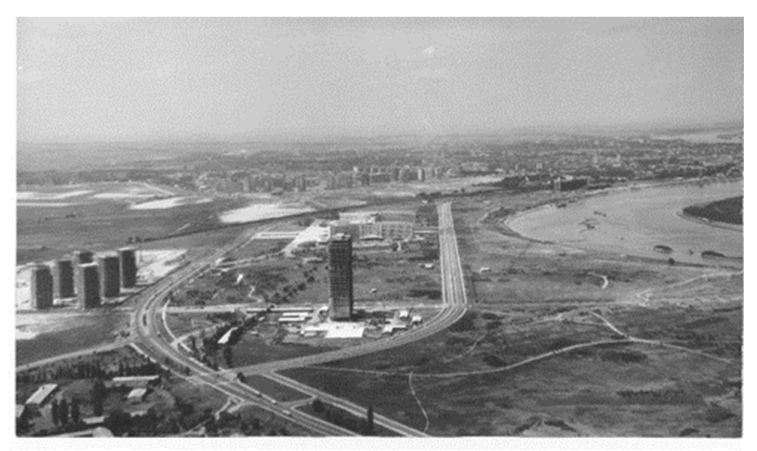

(b)

Figure 6. (a) Conceptual Plan of New Belgrade. Model. Urban Planning Institute of Belgrade \& architect Nikola Dobrović, 1948. Source: [41] (p. 13); (b) Aerial view of the future green area at the confluence, 1963. In front: the Central Committee building; left: housing. Belgrade City Museum, signature: Ur_12495. 
Officially, construction started on April 11th 1948, and the largest part of construction work was carried out by youth working brigades from all parts of Yugoslavia. Building the river embankments, earthwork and planting the first trees were all part of the process. The greening began along the Danube, at the scattered locations that today form the rich and diverse greenery of the urban park Ušce [42].

\subsection{Layers of New Belgrade Landscape: The Danube Riverfront Revisions (from 1960)}

The proposal for the Master plan for New Belgrade from 1960-after years of political and economic crises caused by the Yugoslav-Soviet split-although quite different from the initial plans, managed to build (at least formally) on Dobrović's conception of city landscape. Thus, the Danube riverbank, a space that linked three key buildings in the previous plan, was earmarked as a new, open public space - a great representational park. Beginning in the 1960s, there were several design competitions for key cultural and political state institutions situated in this area, as well as for the special part of the green zone at confluence: the Park of Friendship.

\subsubsection{0: The Park of Culture, Science and Politics}

The 1960 plan provided for a large promenade along the axis that connected the Central Committee building with the most exposed part of the riverbank, which was to end at the Museum of the Revolution (Figure 7a,b). Both sides of the axis were projected to have buildings for culture, science and politics. Yet, the only part of this plan that was completely realised was the Museum of Contemporary Art, opened in 1965. It was designed by Ivanka Raspopović and Ivan Antić, both prominent architects at the time, and the building became a paragon of post-war modernism in Yugoslavia. The winning project of the 1961 competition for the Museum of the Revolution, by architects Vjenceslav Richter and Boris Antunović, also garnered a lot of public and expert attention. However, after a period of reworking the preliminary draft, it was decided that the Museum should be moved to a new site, because, "due to its dimensions and rigid geometry, it has an aggressive effect in one of the most serene city landscapes, at the junction of the two large rivers", and "its height (... ) would cause disharmony with the recently opened Museum of Contemporary Art" [44] (p. 1). A new site was found between the building of the Central Committee and the building of the Presidency. In addition, yet, shortly after construction began in 1978, the whole enterprise was interrupted and finally abandoned in 1980 . Subsequent studies showed that the reasons were not only in the domain of aesthetics, nor in the financial shortages as officially claimed, but in its vestigial ideological and political content $[23,26]$.

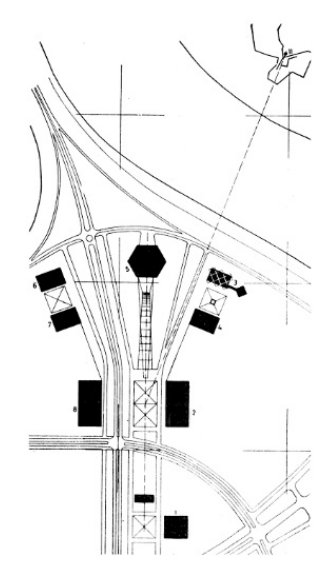

(a)

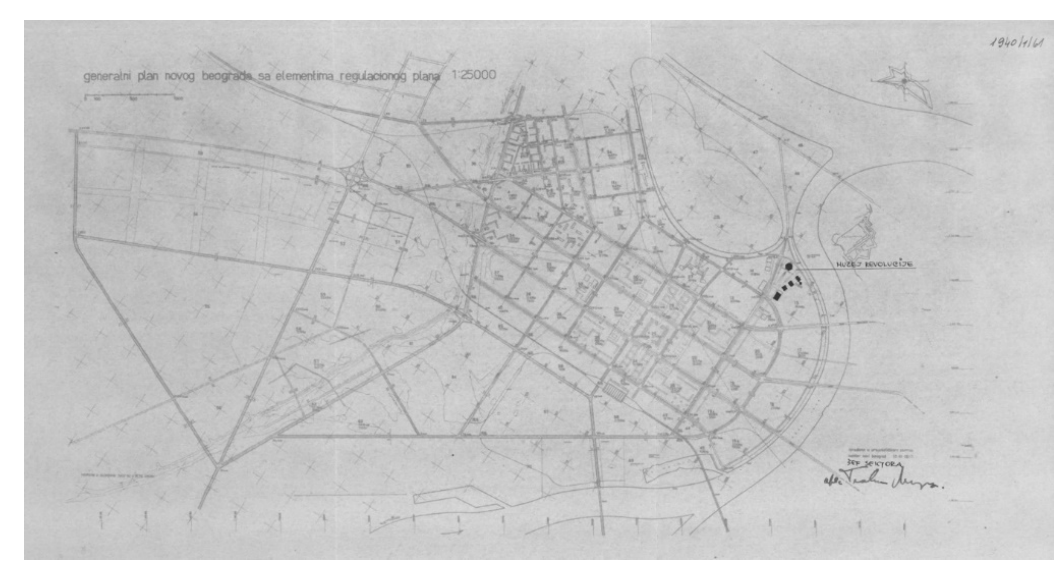

(b)

Figure 7. (a) Site plan of the complex of museums and government buildings at the confluence, in New Belgrade, 1960. Source: [43] (p. 33); (b) Location of the Museum of the Revolution and the Museum of Contemporary Art, New Belgrade. Master plan of New Belgrade with the elements of Regulation plan, 1961. Source: [23] (p. 254). 


\subsubsection{1: The Park of Friendship and the Confluence}

Following the first premise of the Draft, the visionary conception of the city landscape, and the numerous procedures coordinated by the Urban Planning Institute, the green space of New Belgrade was conceived, planted and maintained as a whole. It consisted of a series of modern parks such as the Park of Friendship, the Park of Art, the Sava park and two city parks planned to be set laterally in relation to the building of Presidency. The Park of Friendship was conceived by Vladeta Đorđević and opened in 1961, on the occasion of the First Conference of the Nonaligned Movement. It was formed as a representational space for which 26 participating countries at the Conference planted a tree each in the Alley of Peace, a symbol of commitment to peace and friendship among nations. The park is immersed in the large green space of the Confluence, and the boundaries, in terms of meaning and space, between the two blur [45].

In 1965, Milan Pališaški's entry won the first prize at the all-Yugoslav competition, and its geometric layout remains the most definite space in this riverscape (Figure 8a). Its triangular composition became the basis for further development of this space, though it has never been fully realised. Among other elements of the Park, its central motif (an abstract sculpture on an elevated platform) remained on paper only. Instead, in 2000, the central spot of the Park of Friendship was taken by the monument of the Eternal Flame (Figure 8b). It is dedicated to the victims of the 1999 NATO bombing of Serbia (when the Central Committee building and the Hotel Yugoslavia were also severely damaged).



(a)

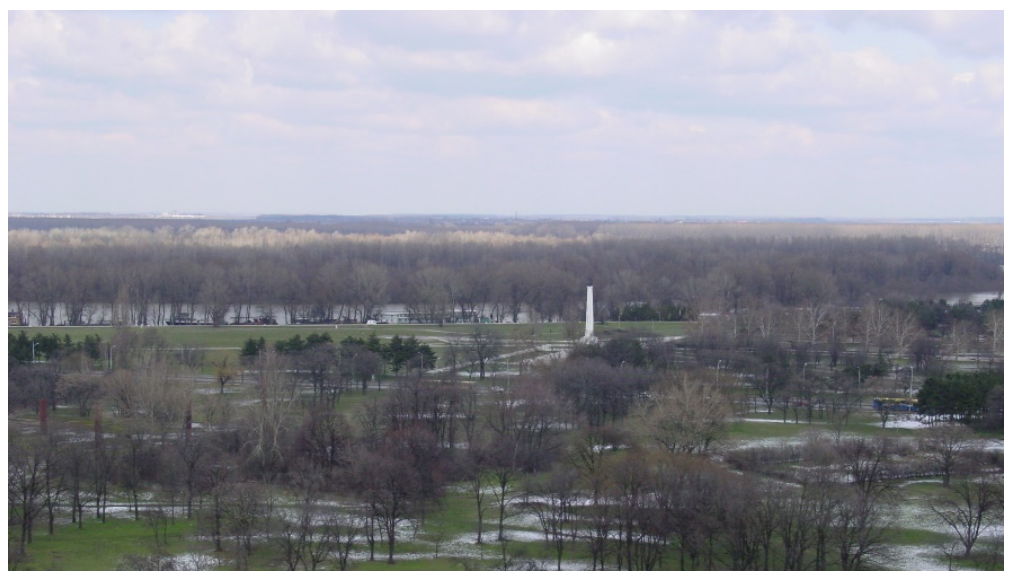

(b)

Figure 8. (a) Milan Pališaški, the competition project for the Park of Friendship at the Confluence, 1965. Source: [45] (p. 206); (b) The Park of Friendship with the monument of the Eternal Flame by Svetomir Radović. Photo by Marija Milinković, 2011.

\subsubsection{2-2003: The Natural Core of Belgrade}

A significant change to the function of the area around the confluence was made in the General Urban Plan of 1972. It removed the idea of turning the arm of the Danube into a lake, preserving the existing form and function of the Great War Island [46]. Although this conception of the space remained in place for the next two decades, after 1991, this area was neglected. The Socialist Federal Republic of Yugoslavia entered the last stadium of a comprehensive social crisis, which resulted in its own dissolution, disintegration of the existing political and economic system and beginning of the transition to capitalism. The post-socialist period started in 2000, with the coming of democratic political opposition to power.

The 2003 General Plan further developed aspects of preservation and enrichment of the natural structures surrounding the confluence, including Kalemegdan park in old Belgrade, Park of Friendship, the continuous strip of green along Sava's left bank, as well as the Čaplja Island and area on the left 
bank of the Danube [47]. The plan thus included the formation of green riverbanks entitled "Natural Core of Belgrade", with the Great War Island at its centre [47,48].

\subsubsection{Epilogue}

On January 24th 2017, the Danish urban design firm Gehl Architects submitted their strategic re-design of the New Belgrade urban park Ušce $[49,50]$. This preliminary landscape project of the site became the blueprint for ambitious plans of the city government for this area. From the perspective of the ongoing transformation of this open public space, our study was conceived as an investigation of the intrinsic pre-existing qualities of the space (Figure 9). The Gehl Architects' plan for the Confluence was announced after the adoption of the new General Urban Plan of Belgrade, in March 2016 [51]. This document also made possible and legitimate the realisation of the Belgrade Waterfront Project, on the right bank of the Sava, whose ongoing development has provoked many controversies [52].

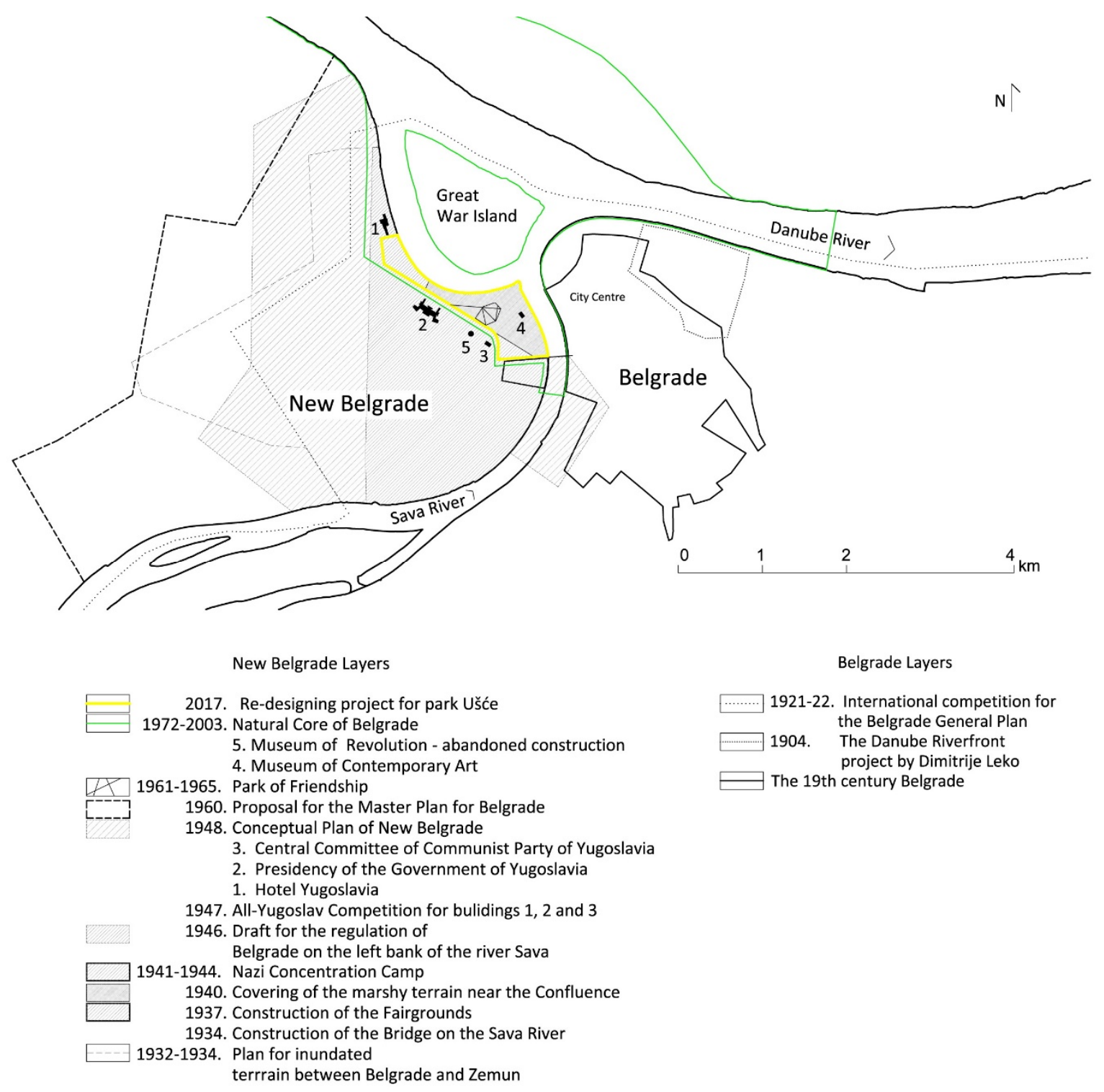

Figure 9. Synoptic map: Spatio-temporal superimposition of historical layers of New Belgrade riverscape (design by Zlata Vuksanović-Macura). 


\section{Discussion of the Case of Confluence}

The analysis implemented in our enquiry is conceived as a contribution to a more comprehensive research procedure that examines the present condition of the New Belgrade urban landscape, more precisely the open public space at the rivers' confluence. Our systematization of historical data was guided by the notion that for this particular mode of historical survey it is less important to extend the scope of existing knowledge than to set up methodological guidelines for this type of research. Namely, this analytical probe was centred on establishing the relationship between the critical practice of landscape architecture and urban planning, at one side, and the critical method of historical enquiry, at the other. The latter is discussed in broader terms in Tafuri's Theories and History of Architecture, under the term of the 'critical history' (storia critica) [22,23]. Yet, the relationship between historical survey and architectural practice has rarely been productive, and even Tafuri insisted on their separated development. Nevertheless, the examples of such productive relationship, even if rare, might be found in various historical periods. For example, the renowned architect Philippe Rahm, in the elaboration of his theoretical concept of 'meteorological architecture', calls for a critical understanding of historical examples of cities, that is campi di Venezia [53]—'an ingeniously conceptualized rainwater filtering and collecting system' that also represents 'spatio-social and cultural network' of the city [54] (p. 27). In our study, profound historical enquiry of the New Belgrade riverscape revisions, covering the spectrum of environmental and societal conditions, intervened in the complex network of historical layers that depict critical moments in formation of the physical structure.

The assay started with the proposition of theoretical and methodological framework and led towards an interpretation of the assimilated knowledge. The results of the research are presented through the synoptic map, and are additionally sublimated in a complementary synoptic diagram (Figure 10).



Figure 10. Synoptic diagram: spatial superposition of historical strata distinguished through critical analysis of historical data (design by Zlata Vuksanović-Macura).

The synoptic map (from Ancient Greek $\sigma v v o \pi \tau \iota k o ́$, sunoptikós, 'seeing the whole together or at a glance') indicates that the distinguished layers are not only historically superposed one onto another, 
but that they intervene with one another more profoundly, forming a complex state of circumstances that we have addressed with the conceptualization of urban landscape. In the synoptic diagram we have distinguished five historical strata (a set of layers) that contribute significantly to comprehension of the present state. By looking at the traces of the formative period of Belgrade urban landscape, the moments of New Belgrade's inception, inerasable impacts of war, vigorous post WWII socialist transformation and, finally, the series of Danube riverscape revisions, we intend to depict the complexity of the modern city legacy and thus stress the interconnectedness of past and future endeavours. Their spatial distribution also reveals the relationships between the initial subject matter, represented by the historical stratum, labelled in the diagram as Revision, and the broader spatial and historical context. Depending on how seriously the site survey is taken, the number of historical layers that are taken into account enhances, and the distinction of the historical strata becomes more precise.

Our research shows the lessons of socialist city planning in conceptualising and building an urban environment that in many aspects advanced the conditions of living in a metropolis. These advantages become conspicuous in comparison to pre-modern and post-modern social and spatial practices: by connecting the private domain of high-quality mass housing and a novel kind of public open spaces within continuous greenery, the modern city offered an alternative to traditional forms of city dwelling. Paradoxically, rigorous planning strategies proved to be rather adaptive to new and constantly changing conditions of the contemporary urban environment and of the world at large. Its solid infrastructure and incompleteness thus provided good conditions for the post-socialist market-driven urban development. Regarding today's complex global situation with regard to the making of urban sustainability and resilience in cities, contemporary research in Serbia is identifying problems in the spatial distribution of green spaces within the Belgrade administrative area, finding they are caused by lack of instruments in "legal adoption and implementation at the local level of planning and managing" in green infrastructure delivery [55] (p. 492). Through the accumulation of ideas and conceptions, New Belgrade long ago stopped being a no-man's wetland. In this respect, the results of our investigation can be considered a point of departure for pursuing new, contemporary critical practices of rethinking and reimagining of (New) Belgrade urban riverscapes.

Likewise, in the projects of the riverscape planning we have acknowledged the impact of both immanent and transcendent critique, exemplary in the work of Leko and Dobrović. Without an enabling social mechanism, critical projects are often rejected, and the redrawing of Leko's plan testifies to that. Yet, the way it was conceived and argumented may still give us a clue about how to conceptualize immanent but severe critique by way of a landscape project. Compared to Leko's plan from 1904, the criticality in Dobrović's work operated in a transcendental mode, as an avant-garde critique that fundamentally altered the heritage of pre-war urban practice. Although the impact of Dobrović's criticism was huge, it was nevertheless limited-resulting in New Belgrade becoming a complex and heterogeneous modern city. By comparing these profoundly differing practices regarding the socio-economic context in which they occurred, we would assume that even today, in fundamentally altered social and political conditions and almost without any enabling mechanism, new modes of criticality may be invented.

Finally, we would argue that the major pitfall of modern (and contemporary) city planning, in both socialist and capitalist economic systems, seems to be the old Faustian trap of considering unbuilt space as emptiness, ready to be filled. As shown in many previous cases, such insensitivity towards local histories and cultural geographies, have made too many projects go astray. Thus, we would like to underline the necessity of assimilating our particular, contemporary moment in history, always defined in critical relation to the complex cultural layers of the past, and directed towards the more heterogeneous, that is, resilient and sustainable, visions of future. In an era when cities are progressively built in an "ad-hoc project modus" [9] (p. 625), the aim of this paper was to challenge the globalizing tendencies of built environments by contributing affirmatively to the critical projects of the urban landscape. Prompted by ongoing processes of re-programming and 
'thematisation' of the extremely important and large part of the New Belgrade riverfront, this study suggests closer examination of the material and immaterial layers of the existing space.

A closer look into the specific history of planning, constructing and inhabiting of the modern city of New Belgrade, and in particular its riverfronts, might prevent such shortcomings and open different and unique perspectives for re-conceptualizing its urban landscape. It can bring not only a better understanding and comprehension of the specificities of the place, but it might be the very source of imagination [10]. These notions may be inapplicable in present conditions, since the detailed plan for the Ušće park has been adopted by the city authorities. Nevertheless, our study's significance is not only didactic, since the Case of Confluence exceeds the re-modelling of one city park, and might prove edifying in the face of new long-term challenges to sustainability of modern cities.

Author Contributions: In preparing of this manuscript, the original paper presented at the conference has been significantly expanded. To include the valuable comments and general insights from the conference, M.M. and D.Ć.; extended the original paper by structuring the theoretical framework and enhancing the scopes of the initial historical enquiry. Z.V.-M. wrote some new parts of the paper, offered proposals and comments, and drew Figures 9 and 10 (Synoptic map and Synoptic diagram). The Discussion of the research manuscript also aroused from the new set of findings.

Funding: This research received no external funding.

Acknowledgments: The translation of quoted works not published in English are by Edward Djordjevic, and the authors are grateful to him for detailed English proofreading of the first version of the manuscript. The authors are also grateful to two anonymous reviewers for the close reading of the previous version of this article and the most constructive comments. This paper was realized as a part of the project "Studying climate change and its influence on the environment: impacts, adaptation and mitigation" (III 43007) and the project "Geography of Serbia" (III 47007) supported by the Ministry of Education and Science of the Republic of Serbia, within the framework of integrated and interdisciplinary research.

Conflicts of Interest: The authors declare no conflict of interest.

\section{References}

1. Lefebvre, H. Social Space. In The Production of Space, 2nd ed.; Blackwell Publishing: Malden, MA, USA, 2008; pp. 68-168.

2. Wang, Y.; Dong, W.; Boelens, L. The Interaction of City and Water in the Yangtze River Delta, a Natural/Artificial Comparison with Euro Delta. Sustainability 2018, 10, 109. [CrossRef]

3. Haslam, S.M. The Riverscape and the River; Cambridge University Press: Cambridge, UK, 2008.

4. Petričić, B. Ambijenti i prostorne vrednosti Beograda [Ambient and spatial values of Belgrade]. Godišnjak grada Beograda 1977, 24, 319-330.

5. Ćorović, D.; Blagojević, L. Water, Society and Urbanization in the 19th Century Belgrade: Lessons for Adaptation to the Climate Change. SPATIUM Int. Rev. 2012, 28, 53-59. [CrossRef]

6. Girot, C.H. Four Trace Concepts in Landscape Architecture. In Recovering Landscape, Essays in Landscape Architecture; Corner, J., Ed.; Princeton Architectural Press: New York, NY, USA, 1999; pp. 59-67.

7. Djalali, A.; Vollaard, P. The Complex History of Sustainability: An index of Trends, Authors, Projects and Fiction. 2008. Available online: https://rasmusbroennum.files.wordpress.com/2011/09/the-complexhistory-of-sustainability-timeline.pdf (accessed on 21 December 2018).

8. Waldheim, C. The Landscape Urbanism Reader; Princeton Architectural Press: New York, NY, USA, 2006.

9. Shennon, K. Landscapes. In The SAGE Handbook of Architectural Theory; Greig Crysler, C., Cairns, S., Heynen, H., Eds.; SAGE Publishing Inc.: Thousand Oaks, CA, USA, 2012; pp. 625-638.

10. Corner, J. Introduction: Recovering Landscape as a Critical Cultural Practice. In Recovering Landscape, Essays in Landscape Architecture; Corner, J., Ed.; Princeton Architectural Press: New York, NY, USA, 1999; pp. 1-28.

11. Frampton, K. Toward an Urban Landscape. In Columbia Documents; Columbia University: New York, NY, USA, 1995; pp. 83-93.

12. Berrizbeitia, A. Re-Placing Process. In Large Parks; Czerniak, J., Hargreaves, G., Eds.; Princeton Architectural Press: New York, NY, USA, 2007; pp. 174-197.

13. Antrop, M. Why landscapes of the past are important for the future. Landsc. Urban Plan. 2005, 1-2, 21-34. [CrossRef] 
14. McHarg, I. Design with Nature; Published for the American Museum of Natural History; Natural History Press: Garden City, NY, USA, 1969.

15. Berrizbeitia, A.; M'Closkey, K. Critical Practices in Modernism: Origins in Nineteenth-Century American Landscape Architecture. In Modernism and Landscape Architecture, 1890-1940; O'Malley, T., Wolschke-Bulmahn, J., Eds.; The National Gallery of Art, Center for Advanced Study in the Visual Arts: Washington, DC, USA, 2015; pp. 205-224.

16. Jackson, J.B. The Word Itself. In Discovering the Vernacular Landscape; Yale University Press: New Haven, CT, USA, 1984; pp. 1-8.

17. Antrop, M. A brief History of Landscape Research. In Landscape Reader; Howard, P., Thompson, I., Waterton, E., Eds.; Routledge: London, UK, 2013; pp. 12-22.

18. Sauer, C.O. The Morphology of Landscape. Univ. Calif. Public. Geogr. 1925, 2, 19-53.

19. Wylie, J. Introduction. In Landscape (Key Ideas in Geography); Routledge: London, UK, 2007; pp. 1-16.

20. Deriu, D.; Kamvasinou, K. Critical perspectives on landscape: Introduction. J. Arch. 2012, 1, 659896. [CrossRef]

21. Ćorović, D. Beograd kao evropski grad u devetnaestom veku: transformacija urbanog pejzaža [Belgrade as a European City in the Nineteenth Century: Urban Landscape Transformation]. Ph.D. Dissertation, Faculty of Architecture, University of Belgrade, Belgrade, Serbia, 2015.

22. Tafuri, M. Theories and History of Architecture; Granada: London, UK, 1980.

23. Milinković, M. Arhitektonska kritička praksa: teorijski modeli [Architectural Critical Practice: Theoretical Models]. Ph.D. Dissertation, Faculty of Architecture, University of Belgrade, Belgrade, Serbia, 2013.

24. Leko, D.T. Revizija regulacionog plana prestonice i njenog građevinskog zakona III [The revision of the regulation plan of the capital and related law on construction]. Tehnički Glasnik [Tech. J.] 1901, 10, 1-2.

25. Sohn, E. Hans Bernhard Reichow and the concept of Stadtlandschaft in German planning. Plan. Perspect. 2003, 2, 119-146. [CrossRef]

26. Blagojević, L.J. Novi Beograd: osporeni modernizam [New Belgrade: Contested Modernism]; Zavod za udžbenike, Arhitektonski fakultet Univerziteta, Zavod za zaštitu spomenika: Belgrade, Serbia, 2007.

27. Dobrović, N. Što je gradski pejzaž-Njegova uloga i prednost u savremenom urbanizmu [What is the City Landscape-Its Role and the Advantage in Contemporary Urban Planning]. Čovjek i Prostor [Man Space] 1954, 20, 1-3.

28. Tuan, Y.-F. Space and Place, The Perspective of Experience; University of Minnesota Press: Minneapolis, MN, USA, 2001.

29. Ćurčić, S. Period of Turmoil, circa 1250-Circa 1450. In Architecture in the Balkans: From Diocletian to Süleyman the Magnificent; Yale University Press: New Haven, CT, USA, 2010; pp. 507-702.

30. Josimović, E. Objasnenje predloga za regulisanje onoga dela varoši Beograda, što leži u Šancu: sa jednim litografisanim planom $u$ razmeri 1/3000 [Providing the Explanations of the Proposals Meant for Regulating the Part of Belgrade that Is Situated in the Moat, by a Lithographic Plan Scaled 1/3000]; E. Josimović: Belgrade, Serbia, 1867.

31. Vuksanović-Macura, Z. San o gradu: međunarodni konkurs za urbanističko uređenje Beograda 1921-1922 [Vision of the City: International Urban Planning Competition for Belgrade 1921-1922]; Orion Art: Belgrade, Serbia, 2015.

32. Vuksanović-Macura, Z. Generalni plan Beograda 1923: komparacija planiranog i ostvarenog [Belgrade's General Plan 1923: A Comparison of Planned to Completed]. Ph.D. Dissertation, Faculty of Architecture, University of Belgrade, Belgrade, Serbia, 2014.

33. Blagojević, L.J. Realpolitik of Space: Sustenance of the Belgrade Fairground. In Stockholm-Belgrade, Proceedings of the 4th Swedish-Serbian Symposium: Sustainable Development and the Role of Humanistic Disciplines, Belgrade, Serbia, 2-4 October 2008; Palavestra, P., Ed.; Serbian Academy of Sciences and Arts: Belgrade, Serbia, 2009; pp. 129-137.

34. The Open University. Centre for Citizenship, Identities and Governance. Available online: http://www.open. ac.uk/ccig/research/projects/semlin-judenlager-in-serbian-public-memory (accessed on 26 May 2017).

35. Dobrović, N.; Marković, V. Železnički problem Beograda [The Railroad Problem of Belgrade]; Urbanistički institut NRS: Belgrade, Serbia, 1946.

36. Obrazloženje [Explication]; document of the Ministry of Construction of Serbia, the Institute of Urban Planning, the Fund of the Ministry of Construction of FNRJ, F 94; Archive of Yugoslavia: Belgrade, Serbia, not dated.

37. Stojanović, B.; Martinović, U. Beograd 1945-1975. Urbanizam. Arhitektura [Belgrade 1945-1975. Urbanism. Architecture]; Niro Tehnička Knjiga: Belgrade, Serbia, 1978. 
38. Anonymous. Uslovi konkursa [Conditions of the Competition]. Tehnika [Technology] 1946, 11-12, 339-342.

39. Dobrović, N. Obnova i Izgradnja Beograda. Konture budućeg Grada [Reconstruction and Construction of Belgrade. Contours of the Future City]; Urbanistički Institut NRS: Belgrade, Serbia, 1946.

40. Blagojević, L.J. The residence as a decisive factor: Modern housing in the central zone of New Belgrade. Architektúra \& Urbanizmus [Architecture and Urbanism] 2012, 3-4, 228-249.

41. Ilić, L. Uz izgradnju Novog Beograda [On the Construction of New Belgrade]. Arhitektura [Architecture] 1948, 8-10, 9-13.

42. Mišić, B. Palata Saveznog izvršnog veća u Novom Beogradu [The Building of the Federal Executive Council in New Belgrade]. Nasleđe [Heritage] 2007, 8, 129-150.

43. Minić, O. Moderna galerija u Beogradu [A modern gallery in Belgrade]. Arhitektura urbanizam [Arch. Urban.] 1962, 16, 33.

44. Perović, M.; Tomić, V. Elaborat o lokaciji i urbanističko-tehničkim uslovima za Muzej revolucije u bloku 13 na Novom Beogradu [Study on Location and Urbanistic-Technical Conditions for (the Construction of) the Museum of the Revolution in Block 13 in New Belgrade]; Zavod za planiranje razvoja grada Beograda [The Institute for the Developmental Planning of the City of Belgrade]: Belgrade, Serbia, 1977.

45. Vesković, I. Park prijateljstva u Novom Beogradu [The Park of Friendship in Novi Beograd (New Belgrade)]. Nasleđe [Heritage] 2011, 12, 203-216.

46. Generalni urbanistički plan Beograda do 2000 [General Urban Plan of Belgrade to 2000]; Urban Planning Institute of Belgrade: Belgrade, Serbia, 1972.

47. Generalni plan Beograda do 2010 [General Plan of Belgrade to 2010]. Službeni list grada Beograda [Official Gazette of the City of Belgrade] 2003, 27, 901-1080.

48. Simić, I.; Stupar, A.; Djokić, V. Building the Green Infrastructure of Belgrade: The Importance of Community Greening. Sustainability 2017, 9, 1183. [CrossRef]

49. Gehl, J. Cities for People; Island Press: Washington, DC, USA, 2010.

50. Anonymous. Usce Park to Have Seven Zones-We Present Conceptual Design of Belgrade‘s Green Oasis. eKapija. 16 March 2017. Available online: https:/ /www.ekapija.com/en/real-estate/1699074/KZIN-BUP/ usce-park-to-have-seven-zones-we-present-conceptual-design-of-belgrades (accessed on 25 March 2017).

51. Generalni urbanistički plan Beograda [General Urban Plan for Belgrade]. Službeni list grada Beograda [Official Gazette of the City of Belgrade] 2016, 60, 1-106.

52. Grubbauer, M.; Čamprag, N. Urban Megaprojects, Nation-State Politics and Regulatory Capitalism in Central and Eastern Europe: The Belgrade Waterfront Project. Urban Stud. 2019, 649-671. [CrossRef]

53. Rahm, P. In Architecture, Precisely. In Precisions: Architecture between Sciences and the Arts; Moravánszky, A., Fischer, O.W., Eds.; Jovis: Berlin, Germany, 2008; pp. 166-195.

54. Blagojević, L.J.; Ćorović, D. Klimatske promene i estetika savremene arhitekture [Climate change and contemporary architecture aesthetics]. In Uticaj klimatskih promena na planiranje i projektovanje [The Impact of Climate Change on Planning and Design]; Djokić, V., Lazović, Z., Eds.; Univerzitet u Beogradu-Arhitektonski fakultet: Belgrade, Serbia, 2011; pp. 19-33.

55. Vasiljević, N.; Radić, B.; Šljukić, B.; Gavrilović, S.; Medarević, M.; Ristić, R. The concept of green infrastructure and urban landscape planning: A challenge for urban forestry planning in Belgrade, Serbia. iForest-Biogeosci. For. 2018, 4, 491-498. [CrossRef]

(C) 2019 by the authors. Licensee MDPI, Basel, Switzerland. This article is an open access article distributed under the terms and conditions of the Creative Commons Attribution (CC BY) license (http:// creativecommons.org/licenses/by/4.0/). 